\title{
Reproductive cycling and hierarchical competition in Cape honeybees, Apis mellifera capensis Esch
}

\author{
HR Hepburn \\ Department of Zoology and Entomology, Rhodes University, PO Box 94, \\ 6140 Grahamstown, South Africa
}

(Received 16 February 1993; accepted 24 June 1993)

\begin{abstract}
Summary - On queen loss, Cape honeybees may requeen from the brood of a queen, an egglaying worker or it may remain as a laying worker colony. These 3 possibilities are reached through 8 different social developmental pathways. The fate of any individual queenless colony varies with brood status and the rates and kinds of worker differentiation that occur on queen loss. Worker differentiation is widespread and includes ovarial and pheromonal development; but only few individuals actually reach "surrogate queen" status. The complex pathways that occur in queenless Cape colonies seem to be determined both by social context and hierarchical competition among workers.
\end{abstract}

Apis mellifera capensis / reproduction / surrogate queen / egg-laying worker / hierarchy / pheromone

\section{INTRODUCTION}

Hierarchical competition for reproductive dominance is continually suppressed by pheromones of the honeybee queen ( $c f$ Free, 1987). On her loss, there is a struggle that includes fighting, development of the ovaries and more queenlike pheromones in the workers (Velthuis et al, 1990). These changes are further modulated by brood and queen cells (Jay, 1968,
1970). In queenless Cape honeybee colonies hierarchical competition is a skein of continually changing and reciprocally interactive variables (Hepburn et al, 1988; Velthuis et al, 1990). In fact, queenless Cape bees may follow at least 8 different pathways of social development. These were examined with respect to brood and the pheromonal and ovarial changes that occur at critical periods in the social developmental pathways on queen loss. 


\section{MATERIALS AND METHODS}

Over a 5-yr period 95 colonies of Apis mellifera capensis averaging about 10000 bees/colony were collected at Grahamstown, hived, and allowed to settle in an apiary. All were dequeened, some were kept broodright $(n=39)$ while others were also debrooded $(n=56)$ and their developmental pathways recorded. Finally, 17 colonies were dequeened, 5 of which had their queens' brood and 12 were debrooded. Five hundred worker bees were collected from each of these 17 colonies on dequeening and 160 bees/colony for each subsequent week, the duration of sampling depending on colony fate. Each bee's head was placed in dichloromethane and its matching and coded abdomen was frozen.

Workers were scored for ovarial development using a slight modification of Velthuis (1970): $0=$ ovaries undeveloped, no compartmentation; 1 = compartmentation visible, but no oocyte development; 2 = ovarioles swollen, 0ocytes spherical; 3 = oocytes bean-shaped; $4=$ oocytes sausage-shaped, ripe. The head extracts were derivatized with BSTFA, concentrated with nitrogen and analyzed with a Hewlett Packard 5890 Series II gas chromatograph fitted with a fused silica column. Six compounds were measured against authentic samples and internal standards: $8 \mathrm{HOA}=8$-hydroxyoctanoic acid; $900 A=9-0 \times 0-2-$ decenoic acid; 9HDAA = 9-hydroxydecenoic acid; 9HDA = 9-hydroxy-2decenoic acid; 10HDAA = 10-hydroxydecenoic acid and 10HDA = 10-hydroxy-2-decenoic acid. At least 50 bees were analyzed for each week of each pathway shown in figure 1. Pheromonal classes are defined as the relative percentage of 9ODA to the other 5 assayed components of the mandibular gland extract: class $1=0-33.3 \%$ 9ODA, $2=33.4-66.6 \% 90 D A$ and $3=66.7-$ $100 \% 90 D A$.

Working definitions of workers are assigned as follows: normal workers = bees in stages 0-1 of ovarial development with a worker-like 9ODA content less than 1/3 of the bouquet compounds measured; laying workers = bees in stage 4, 9ODA content less than 1/3; false queens = bees in stages 0-3, 9ODA exceeds $2 / 3$; surrogate queens $=$ bees of stage $4,900 A$ exceeds $2 / 3$; intermediates $=$ all other permutations. (Note: the categories of workers are defined solely on ovarial and pheromonal content. Their precise behaviours, including whether every bee with ripe eggs actually lays eggs, are not yet known.) Frequency values (tables I and II) are percentages of a kind of bee for the total sample size of its group per specified week. These data were analyzed with the Mann-Whitney $U$-test since all data were at least at the ordinal level of measurement. The test statistic is $z$, not the usua| $U$, because sample sizes were always greater than 20. Significance is defined as $p<0.05$. Statistical comparisons of the developmental pathway events were made using the KruskalWallis test applied to values from an analysis of variance.

\section{RESULTS}

\section{Reproductive cycles}

Four distinct pathways were observed in queenless broodright colonies of the Cape bees ( $P 1-4$, fig 1). The colonies may construct queen cells from available queen brood and simply rear a new queen ("classical requeening", pathway 2), or begin rearing a queen, but abort the whole process only to repeat it with the eggs of a worker (pathway 1). Thirdly, a colony may not construct queen cells but persist for several months only with laying workers and/or surrogate queens (pathway 3), but probably eventually dwindle. Lastly, the colony may abscond (pathway 4), deserting the brood, in which case it enters the broodless pathways (fig 1).

Broodless colonies of Cape bees behave quite differently. If workers become egg-layers then the colonies may persist a long time (pathway 5) just as old colonies do along pathway 3 . Colonies whose workers produce brood may begin to construct queen cells and workers may produce some offspring but the colony soon dwindles (pathway 7) or absconds. Finally some colonies never produce worker brood and either abscond or dwindle (pathway 8 ). 


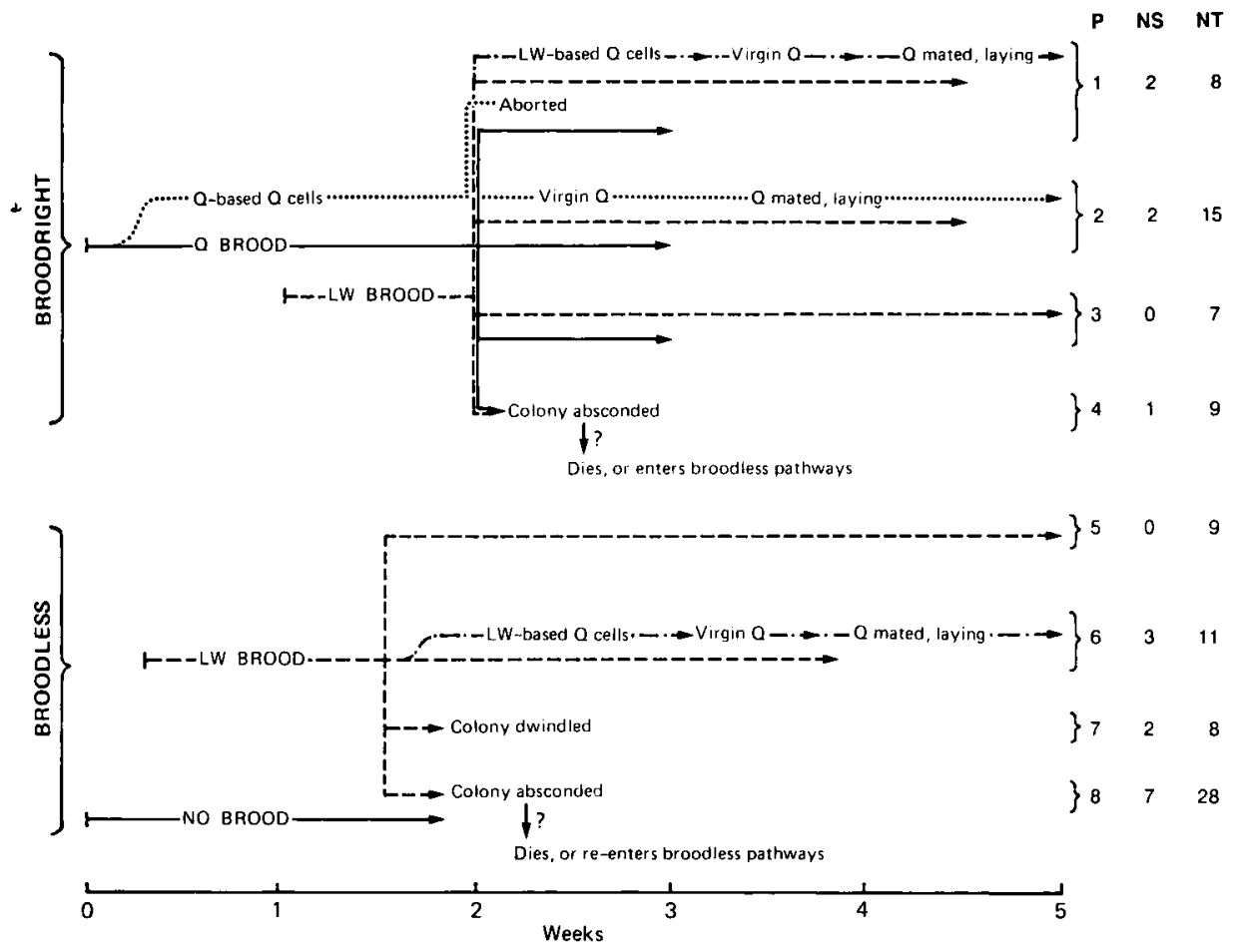

Fig 1. Pathways followed on queen loss in broodright and broodless colonies of the Cape honeybee. Only pathway 2 leads to "classical requeening". Pathways 1 and 6 lead to production of new queens derived from the progeny of laying workers or surrogate queens. Pathway numbers $1-8$ are indicated vertically, at the right of figure. Colonies for which ovarial development and pheromone data are available are given in column NS while the total number of colonies observed over $5 \mathrm{yr}$ (including NT) are given under NT. Time 0 is the initial condition of the colony. Onset and duration of events were estimated by extrapolation from the condition of the colonies at sampling. Thus variations in the precise timing of any particular change cannot be quantified.

On dequeening (week 0 ) the broodright and the broodless colonies did not differ significantly in median ovarial development nor were there any laying workers, false queens or surrogate queens. A median ovarial class of 0 persisted throughout the experiment and indicates that changes occurred among relatively few bees. A week later all colonies (fig 1, table I) contained false queens, most had laying workers (except pathway-4 bees) and surrogate queens (except those of pathway 1 , not considering the absconded and dwindled colonies). These developments occurred despite the presence of queen cells in pathways 1 and 2 and queen brood in pathways 1-3 and worker brood in 6-7.

By the end of week 2, pathway 1 colonies (requeening from laying-worker broods) destroyed previously constructed queen cells. All old queen brood had become capped and all colonies contained new young brood derived from workers (fig 1, table I). At week 3 all colonies contained 
Table I. Within pathway differentiation of workers in broodright and broodless colonies of the Cape honeybee following queen loss. ${ }^{*}$

Pathways

Weeks

Laying workers

False queens

Surrogate queens

(\%)

(\%)

(\%)

1

0

0

0.3

0.3

5.6

1.3

0.3

0

1.9

2

2

3

4

5

3.5

0.3

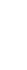

6

0.3

1.4

0

0

0

2

$\begin{array}{ll}0 & 0 \\ 1 & 3.1 \\ 2 & 0.3 \\ 3 & 3.4 \\ 4 & 0 \\ 5 & 0\end{array}$

0

0

3.1

2.8

0.6

0.3

1.3

0

3.4

1.6

0

0

0

0

0

0

4

$\begin{array}{ll}0 & 0 \\ 1 & 0 \\ 2 & 0\end{array}$

0

0

0

0

0.6

0

0.6

0

6

$\begin{array}{lcll}0 & 0 & 0 & 0 \\ 1 & 4.4 & 1.5 & 0.4 \\ 2 & 6.3 & 0.9 & 0.2 \\ 3 & 14 & 0.7 & 0.2 \\ 4 & 6 & 0 & 0 \\ 5 & 5.9 & 0 & 0\end{array}$

7

$\begin{array}{ll}0 & 0 \\ 1 & 1.3 \\ 2 & 1.3\end{array}$

0
1.3

0

0

0.6

0

0

1.3

0

8

0
0.6

0

0

1.9

0

\footnotetext{
* Pathways as illustrated and explained in figure 1; pathways 3 and 5 are omitted because of insufficient data.
} 
mixed-age brood derived from workers and there were capped queen cells in pathways 1, 2 and 6 . The percentages of laying workers, false queens and surrogate queens were significantly elevated compared to week 2 . By week 4 , bees of pathways 1, 2 and 6 had either virgin or mated queens. The other colonies had either dwindled or absconded. Now there were significant reductions in the percentages of laying workers, false queens and surrogate queens (table I). By the end of week 5 , pathway 1,2 and 6 colonies had returned to 'normal status' and were headed by mated, laying queens and the reproductive workers had disappeared (fig 2).

In these developmental sequences only 15 colonies $(15.8 \%)$ followed that of "classical requeening" (fig 1 , pathway 2 ). Other queen production was based on worker eggs (fig 1, pathways 1 and 6 , $20 \%$ ). As a general trend the relative percentages of laying workers, false queens and surrogate queens all increased from week 0 to week 3 and then all went into decline with the appearance of newly mated queens. However, in pathway 2 (classical requeening) the cumulative frequency of egg-laying workers was significantly less than in colonies that requeened from worker brood (table 1). In pathway 6 (requeening from worker's progeny) up to $15 \%$ of the workers were potentially reproductive.

\section{Hierarchical competition}

Reproductive differentiation among queenless worker bees with changing colony context is given in table II. On dequeening all colonies were queenright and broodright. Only a few bees showed slight ovarial or pheromonal development. Half of the colonies retained their mother's brood (group 1 = pathways 1 and 2), the other half were debrooded (group 2 = pathways 4, 6 and 7). Samples collected $7 d$ later (week 1) significantly differed from those of week $O(Z=20.9$ for $O D, Z=5.5$. for 9ODA) but not from each other as groups. Within a week both groups had developed laying workers, false queens and surrogate queens as well as intermediates (table II).

As the colonies entered the second week of queenlessness the context of group 1 (pathways 1 and 2) had changed to contain brood, queen cells and differentiated workers; that of group 2 (pathways 4,6 and 7) included the brood of laying workers and/or surrogate queens as well as differentiated workers. All colonies were now broodright but group 1 colonies had more brood than group 2. At week 2, group 2 colonies also had developing queens and there was a significant increase in laying workers compared to week $1(Z=3.8$ for $O D)$. There was no significant change in worker differentiation in group 1 between weeks 1 and 2 (table II).

During the third week of queenlessness, contextual differences between groups 1 and 2 dissipated. The original queen's brood of group 1 had matured and eclosed; its remaining brood was (like group 2) that produced by laying workers and/or surrogate queens. By the next sample time (week 3 = pathways 1, 2, 4, 6 and 7) all colonies had converged on the same developmental pathway and contained either very ripe queen cells or just eclosed virgin queens. Group 1 reared queens from their original queen's progeny, group 2 from the progeny of laying workers or surrogate queens. Because the social context for both groups was now virtually identical they were combined. At week 3 (table II) worker differentiation had virtually doubled. There were many intermediates and significantly more laying workers $(Z=12.1)$ and significantly more pheromonal change $(Z=0.45)$.

In the ensuing week, the developing or just emerged young queens had mated 
just prior to sampling at week 4 . Now there was a significant reduction in ovarial development $(Z=-6.7)$ and in pheromonal development $(Z=-10.7)$ compared to week 3 (table II). These workers were largely intermediates, the process of reproductive differentiation in workers now being reversed. By the 5th week all of the colonies were classically queenright and headed by mated, laying queens. At the last sampling interval (week 5) worker differentiation had significantly regressed in both ovarial $(Z=$ $-2.8)$ and pheromonal $(Z=-2.9)$ terms.

\section{DISCUSSION}

The reproductive options open to Cape bees on queen loss are classical requeen- ing, requeening from worker brood or remaining as a laying-worker colony. About $60 \%$ of the broodright colonies requeened from either queen's or worker's brood leaving $40 \%$ to proceed as laying worker colonies (fig 1). Only $20 \%$ of the colonies successfully requeened from laying worker brood. Nearly $40 \%$ of the queenless colonies absconded (about $20 \%$ of the broodright and $50 \%$ of broodless colonies). The fates of these colonies are not known. Nevertheless, thelytoky in Cape worker bees is a regular reproductive pathway for this race. The frequencies of this and other pathways followed is related to brood context and possibly to seasonal influences. Aimost all of the data (fig 1) is derived from fall and winter, when queenless Cape swarms are commonplace and colonies

Table II. Frequency distribution of ovarial and pheromonal development as classes of workers in queenless colonies of Cape honeybees*.

Groups

Weeks

\begin{tabular}{llllll}
\hline 0 & 1 & 2 & 3 & 4 & 5
\end{tabular}

\section{Group 1}

1 Normal workers

2 Laying workers

3 False queens

4 Surrogate queens

5 Intermediates

6 Bees having ripe eggs

7 Pheromonally queenlike

$\begin{array}{ccc}88 & 29 & 26 \\ - & 1.7 & 0.3 \\ - & 2.3 & 1.6 \\ - & 0.3 & 0.1 \\ 12 & 66.7 & 72 \\ 0 & 11 & 2 \\ 0 & 15 & 11\end{array}$

21
9.6
1.8
0.6
67
17
6

$\begin{array}{cc}25.2 & 30.7 \\ 3.4 & 2.9 \\ 0.1 & 0 \\ 0 & 0 \\ 71.3 & 66.4 \\ 11 & 11 \\ 0.4 & 0\end{array}$

Group 2

1 Normal workers

2 Laying workers

3 False queens

4 Surrogate queens

5 Intermediates

6 Bees having ripe eggs

7 Pheromonally queenlike

$\begin{array}{ccc}88 & 26 & 21 \\ - & 2.9 & 7.5 \\ - & 1.1 & 0.7 \\ - & 0.3 & 0.1 \\ 12 & 69.7 & 70.7 \\ 0 & 13 & 19 \\ 0 & 5 & 3\end{array}$

21
9.6
1.8
0.6
67
17
6

$\begin{array}{cc}25.2 & 30.7 \\ 3.4 & 2.9 \\ 0.1 & 0 \\ 0 & 0 \\ 71.3 & 66.4 \\ 11 & 11 \\ 0.4 & 0\end{array}$

* Data of table I represented by pathways. For week 0 both groups are identical; for weeks 1 and 2 , group $1=$ pathways 1 and 2 , group 2 = pathways 4,6 and 7 ; for weeks $3-5$, groups 1 and 2 are the same. 


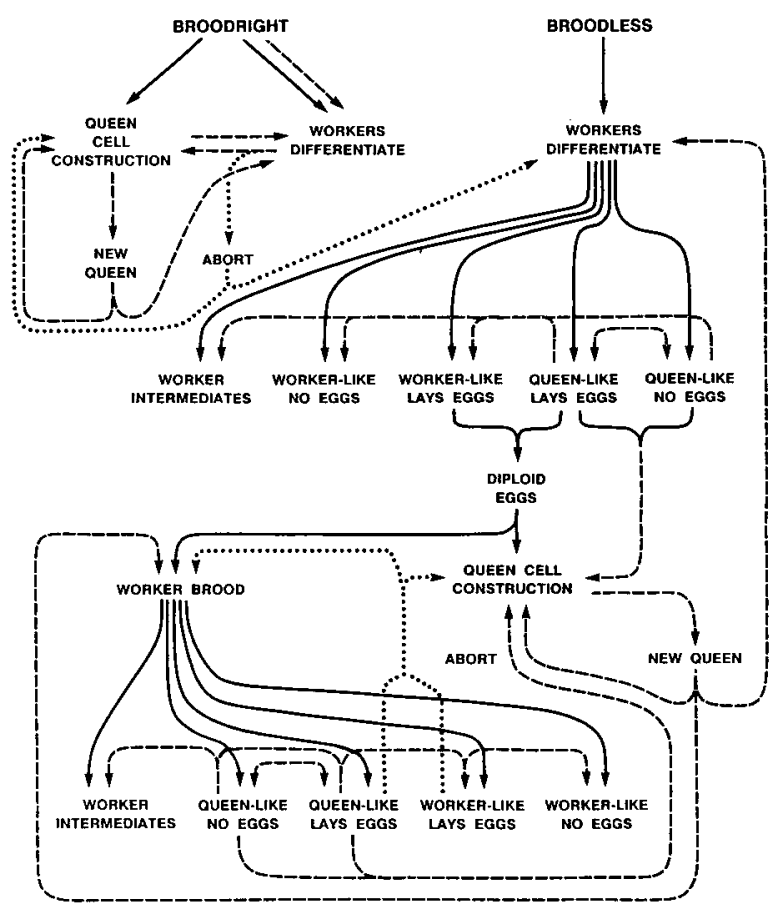

Fig 2. Minimum configurations required for the observed pathways and events associated with queen loss under broodright and broodless conditions in colonies of the Cape honeybee. Solid lines represent step-wise primary processes on which each "bee event" naturally follows from the previous one. Dashed lines represent sequential pathways of inhibitory effects following from a primary process. Dotted lines represent secondary effects that may lead to additional cycles of queen-free reproduction or to queen replacement. The 5 kinds of laying workers indicated in the diagram are not rigidly fixed end-products. Each of these ought to be able to develop one into the other. For simplicity, all intermediates have been omitted.

abscond leaving all stages of brood behind (Hepburn et al, 1988).

Turning to the social milieu of the queenless nest, broodrightness and broodlessness in the Cape honeybee are radically different from the same contexts in other races of honeybees (Ruttner and Hesse, 1979). In queenless Cape honeybees, uncapped brood stimulates queencell construction and partially inhibits ovarial development in workers (Hepburn et al, 1988). If queen rearing proceeds, further queen-cell construction is inhibited as is reproductive differentiation among workers (Whiffler and Hepburn, 1991). As more of the brood of the former queen is capped, reproductive differentiation of the workers becomes derepressed which in turn inhibits queen-cell construction and may even include the destruction of existing queen cells (Hepburn et al, 1988).

Thus there is competition involving the developing queens and the differentiating workers (fig 2). If a queen emerges and 
mates, she inhibits queen-cell construction, worker differentiation and causes differentiated workers to regress, all in one fell swoop (Whiffler and Hepburn, 1991). If, however, workers have differentiated far enough toward surrogate queenship prior to emergence of a queen, queen rearing may be abandoned and, if broodless, the colony may enter pathways of the broodless context (figs 1 and 2, Hepburn et al, 1988). In queenless colonies the absence of brood and developing queen cells derepresses ovarial development (Allsopp, 1988), leads to changes in the pheromonal bouquet of the mandibular gland (Hemmling et al, 1979), and the development of hierarchical dominance (Hillesheim et al, 1989) among workers. These race-specific traits (Ruttner and Hesse, 1979) have different heritability indices (Moritz and Hillesheim, 1985) and operate under different constraints.

The data of table II substantiates this interpretation but show that the rates of ovarial and pheromonal development and subsequent regression are not the same. On dequeening (week 0 ) there are no ripe eggs or queenlike pheromones among the workers. In group 1, 11\% of the bees have ripe eggs after a week and even up to the emergence of the queen and her mating, $11 \%$ of the bees have ripe eggs. The pheromonal picture is quite different: the queenlike bouquet rises quickly in weeks 1 and 2 but then regresses very quickly with the emergence of the queen. In group 2, more bees have ripe eggs than the bees of group 1 and the queenlike pheromones regress far more slowly (table II). In the absence of brood ovarial development is either stimulated or derepressed yet queenlike bouquets are more prevalent in the presence of brood (group 1) than in its absence (group 2).

Ovarial development is inversely related to age and increases in frequency with extended absence of repressive factors
(Hepburn et al, 1988, 1991). Both the bouquet (Hemmling et al, 1979) and the amount of 9ODA (Crewe 1988) in the mandibular gland varies with age, resulting in a wide pheromonal spectrum of bees from workerlike to queenlike (Hepburn, 1992). Ovarial development and becoming pheromonally queenlike covary (Hepburn, 1992), and, with differentiation, a dominance hierarchy also develops among them (Hillesheim and Moritz, 1987) in which dominants are attacked by other bees (Velthuis et al, 1990). Broodlessness, coupled to the above leads to worker bees of varying status, the frequencies of which vary with changing context (tables I and II; figs 1 and 2). If colonies are queenless for long enough (a couple of weeks) they develop an entirely new range of stimulatory and/or inhibitory properties (Hepburn et al, $1988,1991)$ and these are represented by normal workers, laying workers, false queens, surrogate queens and intermediates (table II).

Worker bees that remain "normal" attack differentiating bees (Velthuis and van der Kerk, 1988), are trophallactically subordinate and are themselves the targets of inhibitory signals from differentiating workers (Hillesheim et al, 1989). Laying workers and surrogate queens are attacked by other workers (Velthuis and van der Kerk, 1988). False queens inhibit queen-cell construction (Whiffler and Hepburn, 1991), worker ovarial development (Velthuis et al, 1990 ) and changes in the pheromonal bouquet of other workers (Hemmling et al, 1979). They are also trophallactically dominant (Hillesheim et al, 1989) and evoke retinue formation in other workers (Velthuis, 1985). Surrogate queens have the properties of both laying workers and false queens and virtually mimic real queens (Ruttner et al, 1976; cf tables I and II). Intermediates remain behaviourally unassayed but may be operationally intermediate in their effects on other bees and 
how they in turn are affected by other bees.

The sequence of possibilities modulated by interactions among queenless Cape worker bees are schematically represented in figure 2. These appear to be the minimal physiological and behaviourial relationships required to explain the stimulatory and inhibitory effects (fig 2) that form the basis of hierarchical competition on queen loss in the Cape honeybee.

\section{ACKNOWLEDGMENTS}

I thank RM Crewe for advice, discussion and for the gift of GC Standards, and HHW Velthuis and RFA Moritz for extremely useful comments on the manuscript.

\section{Résumé - Cycles de reproduction et compétition hiérarchique chez l'abeille du Cap, Apis mellifera capensis Esch. À} la perte de leur reine les abeilles du Cap peuvent soit remplacer la reine à partir du couvain de reine ou du couvain d'ouvrières pondeuses, soit rester orphelines (fig 1). Quatre voies de développement sont étudiées pour des colonies orphelines mais possédant du couvain : 1) remplacement classique de la reine par élevage d'une nouvelle reine ; 2) construction d'une cellule royale de sauveté à partir d'une larve de reine, qui est détruite puis remplacée par un œuf d'ouvrière pondeuse ; 3) aucun essai d'élevage de reine, la colonie continue avec des ouvrières pondeuses et/ou des reines suppléantes ; 4) les colonies peuvent déserter et intégrer la voie de développement sans couvain. Les colonies sans couvain peuvent continuer comme petites unités dirigées par des ouvrières pondeuses et/ou des reines suppléantes (5) ou bien une reine peut être produite à partir d'un œuf d'ouvrière pondeuse (6). Les colonies sans reine ni couvain peuvent également produire une petite descendance d'ouvrières pondeuses mais dépérissent ou désertent rapidement (7). Finalement (8) aucun couvain d'ouvrière pondeuse n'est produit et la colonie dépérira ou désertera (fig 1). Les colonies qui ont déserté peuvent suivre l'une des voies de développement sans couvain ou se joindre à d'autres essaims en vol ou qui se sont regroupés. Dans de tels cas les reines en surnombre, les ouvrières pondeuses et les reines suppléantes sont éliminées de la nouvelle colonie.

Le destin de toute reine varie avec la statut du couvain et les taux et types de différenciation des ouvrières qui existent à la perte de la reine (fig 2). La différenciation des ouvrières orphelines est courante et il existe un large spectre de différenciations ovarienne et phéromonale susceptibles de se produire (tableau I). II comprend les abeilles qui, du point de vue phéromonal, sont semblables aux ouvrières et qui (1) pondent ou (2) ne pondent pas d'œufs et celles qui, du point de vue phéromonal, sont semblables aux reines; certaines pondent des œufs (3), d'autres n'en pondent pas (4). II existe de nombreux autres intermédiaires qui sont des permutations de ces types. Très peu d'ouvrières se différencient en véritables "reines suppléantes" qui sont très proches des reines sur le plan phéromonal et qui pondent des œufs (tableau II). Si l'on examine les fréquences relatives de la différenciation ovarienne et phéromonale chez les colonies orphelines (tableau II) en fonction des 8 voies de développement que peuvent suivre des colonies orphelines (fig 1), on s'aperçoit que la nature de la différenciation des ouvrières semble être déterminée par des interactions complexes, impliquant le contexte social et la compétition hiérarchique entre les ouvrières orphelines (fig 2).

Apis mellifera capensis / reproduction / hiérarchie-dominance / ouvrière pon- 
deuse / reine suppléante / régulation sociale / phéromone

\section{Zusammenfassung - Zyklische Abläufe in der Reproduktion und hierarchische} Konkurrenz bei der Kapbiene, Apis mellifera capensis Esch. Nach dem Verlust der Königin können sich Kapbienen entweder aus der Brut einer Königin oder einer legenden Arbeitsbiene wiederbeweiseln, oder sie können weisellos bleiben (Abb 1). Vier Entwicklungswege für weisellose Völker mit Brut werden dokumentiert: 1) Klassische Beweiselung durch Aufzucht einer Nachschaffungskönigin; 2) Nachschaffungszellen mit Weisellarven, die aber zerstört und mit Ejern legender Arbeitsbienen erfolgreich zu Ende gepflegt werden; 3) Es kommt zu keinem Versuch einer Weiselaufzucht, sondern das Volk existiert weiter mit legenden Arbeitsbienen und/oder Ersatz- (Surrogat-)Königinnen; und 4) Die Völker können ausziehen und den Entwicklungsweg der Brutlosigkeit nehmen. Brutlose Völker können als kleine Einheiten weiter bestehen, mit legenden Arbeitsbienen und/oder Surrogatköniginnen, 5) oder 6) aus dem Gelege einer legenden Arbeiterin kann eine Königin aufgezogen werden. Weisel- und brutlose Völker können 7) ebenfalls einige Nachkommen legender Arbeiterinnen aufziehen, aber bald schrumpfen und schließlich ausziehen. Schließlich 8) wird überhaupt keine Arbeiterbrut produziert und das Volk wird abnehmen und ausziehen (Abb 1). Ausgezogene Schwärme können einen der brutlosen Entwicklungswege nehmen, oder sie vereinigen sich mit einem anderen ausgezogenen Schwarm oder mit einem niedergelassenen Volk. In solchen Fällen werden überzählige Königinnen, legende Arbeiterinnen oder Ersatzköniginnen aus dem neuen Volk entfernt.

Das Schicksal jeder einzelnen Königin hängt vom Brutstatus $a b$ und von dem
Anteil und der Art der ArbeiterinnenDifferenzierung, die nach dem Verlust der Königin eintreten (Abb 2). Eine Differenzierung weiselloser Arbeiterinnen ist häufig und es gibt ein breites Spektrum ovarieller und pheromonaler Differenzierung (Tabelle I). Das umfaßt sowohl Bienen, die nach den Pheromonen Arbeiter-ähnlich sind und die: 1) Eier legen oder 2) dies nicht tun, als auch Bienen, die Pheromone wie eine Königin besitzen und 3) keine Eier legen oder die 4) ein Gelege produzieren. Es gibt zahlreiche andere Zwischenstufen, die als Abwandlungen der oben erwähnten Möglichkeiten entstanden sind. Sehr wenige Arbeitsbienen entwickeln sich zu echten "Surrogatköniginnen", die in ihren Pheromonen sehr Königin-ähnlich sind und die Eier ablegen (Tabelle II).

Werden die relativen Häufigkeiten der Ovar- und Pheromon-Differenzierung bei weisellosen Völkern nach den 8 Entwicklungswegen weiselloser Völker untersucht (Tabelle II, Abb 1), so scheint die Art der Arbeiterinnen-Differenzierung durch komplexe Interaktionen bestimmt zu werden, unter Beteiligung des sozialen Gefüges und der hierarchischen Konkurrenz zwischen weisellosen Arbeiterinnen (Abb 2).

\section{Apis mellifera capensis / Surrogat- Königin / legende Arbeitsbiene / Phero- mone}

\section{REFERENCES}

Allsopp MH (1988) Mandibular gland acids and laying workers in African honey bees. In: Africanized Honey Bees and Bee Mites (GR Needham, RE Page, M Delfinado-Baker, CE Bowman, eds) Wiley, New York, 72-79

Crewe RM (1988) Natural history of honey-bee mandibular gland secretions: development of analytical techniques and the emergence of complexity. In: Africanized Honey Bees and Bee Mites (GR Needham, RE Page, M Delfi- 
nado-Baker, CE Bowman, eds) Wiley, New York, pp 149-158

Free JB (1987) Pheromones of Social Bees. Chapman and Hall, London

Hemmling C, Koeniger N, Ruttner F (1979) Quantitative Bestimmung der 9Oxodecensäure im Lebenzyklus der Kapbiene (Apis mellifera capensis Escholtz). Apidologie 10, 227-240

Hepburn HR (1992) Pheromonal and ovarial development covary in Cape worker honeybees, Apis mellifera capensis. Naturwissenschaften 79, 523-524

Hepburn HR, Nefdt RJC, Whiffler LA (1988) Queen loss in the Cape honeybee: the interactions of brood, laying workers (false queens?) and queen cells. S Afr J Sci 84, 778-780

Hepburn HR, Magnuson P, Herbert L, Whiffler LA (1991) The development of laying workers in field colonies of the Cape honeybee. $J$ Apic Res 30, 13-16

Hillesheim E, Moritz RFA (1987) Genetic variance of physiological characters in the Cape honeybee. J Apic Res 26, 30-36

Hillesheim E, Koeniger N, Moritz RFA (1989) Colony performance in honeybees (Apis mellifera capensis Esch) depends on the proportion of subordinate and dominant workers. Behav Ecol Sociobiol 24, 291-296

Jay SC (1968) Factors influencing ovary development of worker honeybees under natural conditions. Can J Zool 46, 345-347

Jay SC (1970) The effects of various combinations of immature queens and worker bees on the ovary development of worker honey- bees with and without queens. Can $J$ Zool 48, 169-173

Moritz RFA, Hillesheim E (1985) Inheritance of dominance in honeybees (Apis mellifera capensis Esch). Behav Ecol Sociobiol 17, 8789

Ruttner F, Hesse B (1979) Rassenspezifische Unterschiede in Ovarentwicklung und Eiablage von weisellosen Arbeiterinnen der Honigbiene Apis mellifica L. Apidologie 2, 159183

Ruttner F, Koeniger N, Veith HJ (1976) Queen substance bei eierlegenden Arbeiterinnen der Honigbiene Apis mellifica L. Naturwissenschaften 63,434

Velthuis HW (1970) Ovarian development in Apis mellifera worker bees. Entomol Exp App/ 13, 377-394

Velthuis HHW (1985) The honeybee queen and the social organization of her colony. Fortschr Zool 31, 343-357

Velthuis HHW, Van der Kerk A (1988) Age, environment and genes in relation to the mandibular gland secretion of pure and hybrid Apis mellifera capensis worker bees. In: Africanized Honey Bees and Bee Mites (GR Needham, RE Page, M Delfinado-Baker, CF Bowman, eds) Wiley, New York, 79-86

Velthuis HHW, Ruttner F, Crewe RM (1990) Differentiation in reproductive physiology and behaviour during the development of laying worker honey bees. In: Social Insects (W Engels, ed) Springer, Berlin, 231-243

Whiffler LA, Hepburn HR (1991) Inhibition of queen cell construction in the Cape honeybee (Apis mellifera capensis). Apidologie 22, 229-236 